\title{
WPŁYW TEOLOGII KSIĄG KRONIK NA PIERWSZA KSIĘGĘ MACHABEJSKĄ NA PRZYKŁADZIE 2KRN 25,1-28 I 1MCH 11
}

Analiza tekstów jednych ksiąg przez zestawienie ich z tekstami innych nie jest niczym nowym. Egzegeci nazywają ten zabieg badawczy interpretacją wewnątrzbiblijną, a przykłady tego typu lektury są niezwykle częste, zwłaszcza w zestawieniu obu Testamentów. Dla nikogo nie jest niespodzianką wielokrotne cytowanie tekstów Starego Testamentu w Nowym i reinterpretowanie ich w słowach Jezusa, Piotra, Jana czy Pawła. ${ }^{1}$ Wiadomo, że najważniejszą zasadą doboru tekstów w Nowym Testamencie jest kryterium chrystologiczne, czyli spojrzenie na teksty Biblii Hebrajskiej i Greckiej w świetle życia i nauczania Chrystusa. ${ }^{2}$

W samym Starym Testamencie odnaleźć można również wiele tzw. relektur, czyli tekstów pisanych przez jednych hagiografów, następnie podejmowanych w nowym lub szerszym kontekście historyczno-teologicznym przez późniejszych pisarzy natchnionych. Relektury „rozwijają pewne aspekty znaczeniowe tekstu, niekiedy wyraźnie różniące się od sensu pierwotnego albo wręcz cytują wcześniejsze

1 Znakomitą w tym temacie pracę wykonali autorzy poszczególnych części dzieła zbiorowego G.K. B e a 1 e, D.A. C a r s o n (red.), Commentary on the New Testament Use of the Old Testament, Grand Rapids 2007.

2 Tak stwierdza Konstytucja Dei Verbum Soboru Watykańskiego II: „Najgłębsza prawda o Bogu i o zbawieniu człowieka jaśnieje nam przez objawienie w osobie Chrystusa, który jest zarazem pośrednikiem i pełnią całego objawienia” (KO 2) oraz „Chrystus Pan, w którym całe objawienie Boga najwyższego znajduje swe dopełnienie (por. 2Kor 1,3, 3,16-4,6)" (KO 7). Świadomość samego Chrystusa skoncentrowania na Nim objawienia Bożego uwidacznia się m.in. w zapisie Łk 24,27. 
teksty, po to, aby pogłębić ich znaczenie albo stwierdzić ich wypełnienie się w czasie"3.

Również w toku badań nad Pierwszą Księgą Machabejską okazuje się, że autor natchniony obficie korzystał z wersetów ksiąg protokanonicznych, w tym z Ksiąg Kronik. Obecnie posiadamy wyłącznie grecki zapis Pierwszej Księgi Machabejskiej i analiza tego typu wewnątrzbiblijnych relacji tekstowych musi opierać się jedynie na odpowiedzi na pytanie o relację greckiego tekstu Ksiąg Kronik w wersji Septuaginty do omawianego dzieła. Czym więc kierował się autor Pierwszej Księgi Machabejskiej, gdy przytaczał konkretny werset tych dzieł, a ogólnie ksiąg protokanonicznych? ${ }^{4}$ Autorowi niniejszego przedłożenia chodzić będzie o wpływ określonych dwóch ksiąg Starego Testamentu widzianych oczami autora Pierwszej Księgi Machabejskiej przez jego teologiczne spojrzenie w przeszłość. Ogólnie bowiem teksty ksiąg protokanonicznych, w tym także - choć nie głównie - stanowią powielekroć punkt odniesienia w konkretnym, prezentowanym wersecie dzieła autora Pierwszej Księgi Machabejskiej. Sposób jego podejścia do tradycji historycznej wskazuje właśnie

3 O czym szerzej, podając przykłady, wspomina dokument Papieskiej Komisji Biblijnej Interpretacja Pisma Świętego w Kościele, w rozdz. III: Wymiary specyficzne katolickiej interpretacji pisma świętego, sekcja A: Interpretacja Pisma św. w tradycji biblijnej, nr I: Relektury, jako ,,fakt wykorzystywania wcześniejszych pism biblijnych w później powstałych częściach Biblii”, https://biblia.wiara.pl/doc/423149. INTERPRETACJA-PISMA-SWIETEGO-W-KOSCIELE (dostęp: 29 V 2019).

4 Badania nad tekstem Pierwszej Księgi Machabejskiej dowiodły, że hagiograf korzystał z poszczególnych wersetów dosłownie wszystkich ksiąg protokanonicznych, zaś omawiana perykopa Drugiej Księgi Kronik jest tego egzemplifikacją. Wyniki całości refleksji nad Pierwszą Księgą Machabejską zostaną przedstawione w przygotowywanym, drugim tomie komentarza do księgi w ramach serii Nowego Komentarza Biblijnego. Świadomość tej zapowiedzi pozwoli czytelnikowi poprawnie zrozumieć tezy zawarte w dalszej części niniejszego artykułu. Wydany już drukiem, pierwszy tom komentarza do tej księgi jest zapisem toku analizy i interpretacji, która znajduje zastosowanie także w omawianych tu zagadnieniach; zob. J. N a w r o t, Pierwsza Księga Machabejska - rozdziały 1, 1-6,16, Nowy Komentarz Biblijny, ST XIV/1, Częstochowa 2016. 
na teologię, którą każdorazowo wydobywał z wydarzeń zapisanych we wcześniejszych księgach biblijnych.

Uzasadniona wątpliwość powstaje jednak, czy podany w tytule niniejszej pracy przykład jednej księgi (2Krn) może ukazywać całość wpływu tradycji kronikarskiej na teologię Pierwszej Księgi Machabejskiej. Intencją autora niniejszej pracy nie jest udowodnienie, że przykład ów jest reprezentatywny dla przedstawienia sposobu podejścia hagiografa Pierwszej Księgi Machabejskiej do wszystkich tekstów Ksiąg Kronik. Egzegeza wykazuje bowiem, że generalnie inne jest jego odwoływanie się do teologii tekstów prawnych, inne do historycznych, nie wspominając już o poetyckich, zawartych w niektórych partiach Pierwszej Księgi Machabejskiej. ${ }^{5}$ Chodzi zatem bardziej o podanie na konkretnym przykładzie sposobu analizy teologicznej, zastosowanej powszechnie w Pierwszej Księdze Machabejskiej, polegającego na celowym użyciu głównie aluzji, ${ }^{6}$ by na powstałych związkach między wersetami różnych ksiąg budować własną ocenę postępowania głównych bohaterów.

Artykuł niniejszy przytacza zatem jedno z wielu odniesień do tekstów wspomnianych ksiąg, z których korzystał autor Pierwszej Księgi Machabejskiej, tworząc treść własnego dzieła. Zapożyczając nieprzypadkowo poszczególne terminy oraz całe zwroty językowe, ukazuje on bowiem wyraźnie własną myśl, ukrytą pod zapisem, jaki zawarł w poszczególnych wersetach.

W niniejszej pracy zatem, w zarysowanym wyżej świetle, analizie poddaję wpływ omawianego fragmentu 2Krn 25,1-28 na przytoczone poniżej teksty Pierwszej Księgi Machabejskiej (rozdz. 11). Egzegeza ta

5 Zwraca na to ogólnie uwagę m. in. E. M e n n, Inner-Biblical Exegesis in the Tanak, w: A.J. H a u s e r, D. F. W a t s o n (red.), A History of Biblical Interpretation, t.1: The Ancient Period, Grand Rapids-Cambridge 2003, s. 55-79.

6 U. Rappaport nie mówi o aluzjach, lecz o „niebezpośrednich odniesieniach do biblijnych fragmentów oraz wersetów"; por. U. R a p p a p o r t, A Note on the Use of the Bible in 1 Maccabees, w: M.E. S t o n e, E.G. C h a z o n (red.), Biblical Perspectives: Early Use and Interpretation of the Bible in Light of the Dead Sea Scrolls: Proceedings of the First International Symposium of the Orion Center 12-14 May 1996, Leiden-Boston-Köln 1998, s. 175. 
pozwala na otworzenie horyzontu szerszych badań nad powiązaniem Ksiąg Kronik z Pierwszą Księgą Machabejską przez przypomnienie innych postaci obecnych w dziejach narodu wybranego. Ze względu jednak na ograniczoną objętość niniejszej pracy ich wzajemny związek nie zostanie tu ukazany. Jednakże na podstawie przedstawionego i omówionego przykładu (paraleli 2Krn 25,1-28 i 1Mch 11) można pokusić się o nakreślenie pewnej wizji badawczej pomocnej w poszukiwaniu związku między Księgami Kronik a Pierwszą Księgą Machabejską.

Gwoli ścisłości pragnę również zaznaczyć, że w niniejszej pracy nie zajmuję się badaniem relacji tekstu hebrajskiego 2Krn 25,1-28 do jego wersji greckiej. Wykracza to daleko poza ramy wyznaczone tytułem niniejszego artykułu, choć z pewnością taka analiza pozwoliłaby głębiej ukazać ewolucję myśli hagiografów tworzących swe dzieła w różnych okresach historii Izraela. ${ }^{7}$

Głównym bohaterem perykopy 2Krn 25,1-28 jest judzki król Amazjasz, którego życiowe perypetie stały się w Pierwszej Księgi Machabejskiej swoistą kanwą dla teologicznej prezentacji postawy arcykapłana Jonatana. Dokonana analiza wybranych wersetów całego omawianego tu fragmentu przekonuje, że hagiograf księgi celowo przywoływał tę postać z dziejów Izraela, by na jej przykładzie dokonać własnej oceny działań Jonatana.

\section{Poczynania Amazjasza w 2Krn 25 i Jonatana w 1Mch 11}

Obie wymienione w podtytule postaci zestawione zostały przez autora Pierwszej Księgi Machabejskiej na fundamencie tekstu 2Krn 25,1-28, przy czym pierwszorzędnej wagi komentarzem teologicznym do porównania obu bohaterów jest w. 2, w którym autor natchniony

7 Badania takie przeprowadził m.in. R. Good, skupiając się na tłumaczeniu greckim hebrajskich form czasownikowych, por. R. G o o d, The Septuagint's Translation of the Hebrew Verbal System in Chronicles, Leiden-Boston 2010, passim, gdzie czytelnik znajdzie odpowiednie uwagi autora dla omawianego passusu $2 \operatorname{Krn} 25,1-28$. 
akcentuje oddanie króla judzkiego Bogu, lecz jest to oddanie nieszczere, bo pozbawione poświęcenia się sprawie bez reszty. ${ }^{8}$ Grecka wersja tekstu brzmi następująco:

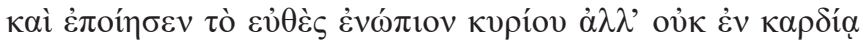
$\pi \lambda \eta ́ \rho \varepsilon \imath$

„Czynił on to, co słuszne przed Panem, lecz nie sercem pełnym".

W całym passusie werset ów pełni rolę wprowadzenia teologicznego (o charakterze generalizującym) w szczegółowy opis konkretnych wydarzeń, który to opis następuje w wersetach kolejnych. ${ }^{9}$ Tam,

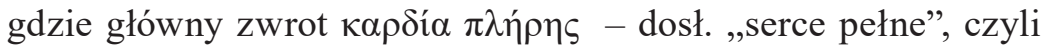
szczere, uczciwe, pełne poświęcenia - odnosi się w Biblii do relacji człowiek - Bóg, oznacza warunek uzyskania Jego pomocy w trudnych sytuacjach życiowych (2Krl 20,3). Właśnie taka, wypływająca z głębi serca szczerość jest najbardziej miła Bogu (1Krn 29,9; 16,9; 19,9; Syr 1,30). ${ }^{10} \mathrm{~W}$ ocenie autora Pierwszej Księgi Machabejskiej zabrakło jej Jonatanowi, który w początkowej fazie swej władzy nad społecznością żydowską swego kraju (po śmierci Judy) postępował drogą wierności Bożym nakazom. W ostatecznej jednak ocenie autora Pierwszej Księgi Machabejskiej nie pozostał wierny, o czym świadczy podobny do Amazjasza koniec jego życia. Cały passus

8 Zdanie to kieruje czytelnika właśnie ku teologicznemu, nie zaś obiektywnemu spojrzeniu na historię króla, prezentowaną tutaj - jak i w całości księgi - w pełnej i ścisłej relacji do postanowień Boga, odgrywającego, przez pośrednictwo posłanego przez siebie proroka, rolę decydującą, por. E. B e n Z v i, History, Literature and Theology in the Book of Chronicles, London-New York 2006, s. 6.

9 Łącznie z w. 1 stanowią one formułę wprowadzającą do całości tekstu, por. S. J a p h e t, I and II Chronicles: A Commentary, Old Testament Literature, Louisville 1993, s. 857.

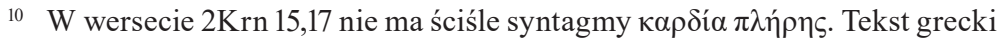

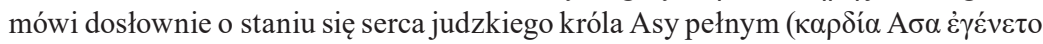
$\pi \lambda \eta ́ \rho \eta \varsigma)$. 
2Krn 25,1-28 rozpatrywany pod kątem wierności Bogu i jej porzuceniu przez króla judzkiego podzielić można na dwa główne etapy:

1. etap wierności (w. 1-10a.11-12), ${ }^{11}$

2. czas pychy i niewierności Bogu (w. 14-28).

Ów drugi etap (czas pychy i niewierności) podzielić można na następujące sekwencje:

- bałwochwalstwo i odrzucenie rady proroka (w. 14-16),

- pycha i samowola króla (w. 17-24),

- podsumowanie (w. 25-26),

- niewierność Bogu i śmierć króla w wyniku spisku (w. 27-28).

Szczyt potęgi Amazjasza przypadł na zwycięską walkę z Edomitami, w której znacznie większą liczbę wrogich wojsk pobił dzięki pomocy Boga (2Krn 25,11-12). Uniesiony zwycięstwem król uczynił rzecz niewybaczalną z punktu widzenia wiary, wprowadził bowiem bożki pogańskie pokonanych Edomitów do swego kraju i oddawał im cześć, co spowodowało natychmiastową, negatywną i ostrą reakcję Boga wypowiedzianą ustami proroka (w. 14-15). Na słowa proroka król odpowiedział postawą arogancką i zatwardziałą (w. 16). Pychę swą pogłębił, wyzywając na wojnę izraelskiego króla, Joasza, co z kolei zakończyło się jego klęską, która nastąpiła z zrządzenia Bożego jako kara za bałwochwalstwo (w. 17-24). Ostatecznie Amazjasz zginął w wyniku uknutego przeciw niemu spisku (w. 27).

Oba główne etapy życia Jonatana z Pierwszej Księgi Machabejskiej przedstawione są w relacji historycznej autora natchnionego na wzór życia Amazjasza. Cezura między oceną pozytywną a negatywną działań Jonatana przebiega w momencie walki toczącej się między panującym w imperium Demetriuszem I a pragnącym odebrać mu koronę Aleksandrem Balasem. Obaj prześcigali się w próbach

11 Bohaterem w. 10b nie jest król, lecz - jako bohater zbiorowy - żołnierze zwolnieni przez niego ze służby. Również pominięty w planie w. 13 ma za swego bohatera zbiorowego tych samych żołnierzy. Bez wyszczególnienia obu wersetów, tę samą strukturę passusu, rozszerzonego do 26,2 rozpoznaje R.W. K 1 e i n, 2 Chronicles, Hermeneia - A Critical and Historical Commentary of the Bible, Minneapolis 2012, s. 353. 
przeciągnięcia Jonatana na swoją stronę obietnicami politycznymi, społecznymi i religijnymi (1Mch 10,1-20), ze szczególnym akcentem na uczynienie go arcykapłanem $(10,20)$. Choć godność arcykapłańska Jonatana nie została mu nadana zgodnie z Prawem Mojżeszowym, lecz na mocy ustanowienia pogańskiego władcy, to jednak dała mu ogromne przywileje. Gdy Jonatan był u szczytu władzy, uhonorowany zarówno przez Aleksandra Balasa jak i faraona Ptolemeusza $(10,60)$, dał się po prostu ponieść własnej pysze, rozpoczynając proces odchodzenia od wierności Bogu i idąc w stronę dbałości o zabezpieczenie interesów rodzinnych. Ostatecznie został zabity w wyniku spisku uknutego przez Tryfona, samozwańczego władcę imperium seleuckiego (13,23). Widać zatem, jak mocno oba życiorysy, Amazjasza i Jonatana, obrały ten sam kierunek w dziejach Izraela.

W tekście Pierwszej Księgi Machabejskiej aluzyjne odwołanie do Amazjasza jako wzorca oceny postępowania Jonatana pojawia się kilkakrotnie, ściśle cztery razy:

$\begin{array}{cc}1 \mathrm{Mch} & 2 \mathrm{Krn} \\ 11,37 & 25,7-9.16 \\ 11,41 & 25,17-19 \\ 11,55 & 25,20.22 \\ 11,72 & 25,20.22\end{array}$

Poniższa syntetyczna egzegeza odnośnych fragmentów pozwoli ujrzeć intencjonalny związek przytoczonych w rubryce wersetów.

W 1Mch 11,37 znajdujemy nawiązujące do działań Amazjasza połączenie czasowników $\pi$ oić $\omega$ oraz $\delta i ́ \delta \omega \mu$, użyte w poleceniu przygotowania ( $\pi$ oı $\tilde{\sigma \alpha l)}$ odpisu dokumentu Demetriusza do Jonatana,

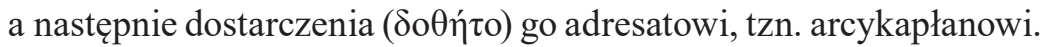
Ma to znaczenie w kontekście spotkania władcy judzkiego z prorokiem $(2 \mathrm{Krn}$ 25,9). Prorok odradzał królowi Amazjaszowi dalsze powoływanie wojsk izraelskich, ponieważ, jak mówi prorok, Pan nie pobłogosławi go w bitwie z udziałem nowego zaciągu. Mniemanie króla, że wzmocni się dzięki kolejnym oddziałom zaciężnym, jest 
płonne (w. 7-8)..$^{12}$ Na pytanie króla, co ma zatem uczynić ( $\pi$ oiñ $\left.\sigma \omega\right)$ z pieniędzmi, które wydał już na najemników, prorok odpowiada,

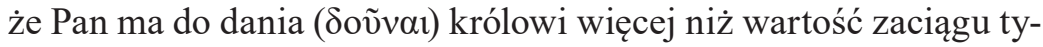
siąca żołnierzy. Czytana w tym świetle perykopa z Pierwszej Księgi Machabejskiej sugeruje, że Jonatan nie powinien był przyjmować zapewnień pogańskiego króla, lecz oprzeć się na Bogu, który da mu o wiele więcej korzyści niż przemijające dobra materialne. Chociaż autor nie wspomina o tym wprost, można przypuszczać, że Jonatan przyjął obietnice króla, skoro nieco później wsparł go swymi oddziałami, wiążąc się politycznie i militarnie z dotychczasowymi ciemiężycielami Izraela. Zabrakło mu więc zaufania do Boga, podobnego do tego, jakiego wcześniej żądał od Amazjasza ówczesny prorok. Jeszcze bardziej sens teologiczny obu przytoczonych wyżej terminów uwidacznia się w ostatnim spotkaniu władcy i proroka, po wygranej przez Amazjasza bitwie z Edomitami (2Krn 25,11-13). Uniesiony sukcesem król wprowadził do swego kraju kult pogańskich bożków, którym cześć oddawał zwyciężony przez niego lud. Sam władca Judy także czcił je w sposób publiczny $(25,14)$. Takim postępowaniem wzbudził przeciw sobie gniew Boga, który posłał proroków ${ }^{13} \mathrm{~W}$ celu zgromienia go i ostrzeżenia przed konsekwencjami braku wierności i roztropności $(25,15)$. Tymczasem rozgniewany na proroka władca zarzucił mu wtrącanie się w sprawy, które nie powinny go dotyczyć, ponieważ on sam, Amazjasz, nie ustanowił ( $\delta \varepsilon \delta \delta \kappa \alpha)$ go swym doradcą. Groził ponadto prorokowi ukaraniem. Zanim zamilkł, prorok

12 Egzegeci zauważają zadziwiający fakt wpierw istnienia jakiejś liczby wojowników niebędących częścią armii króla izraelskiego, potem zaś najmowania ich przez króla Judy bez oficjalnej prośby skierowanej wpierw do panującego w Izraelu władcy. Wnioski prowadzą ku teologicznemu spojrzeniu na Joasza, rządzącego wprawdzie Izraelem, lecz słabego i niepotrafiącego zapanować nawet nad swoim wojskiem, por. E. B e n Z v i, History, Literature and Theology in the Book of Chronicles, s. 61, 75. Takie rozumienie tekstu Drugiej Księgi Kronik pozwala ujrzeć zapożyczenia dokonywane przez autora Pierwszej Księgi Machabejskiej jako czysto teologiczne, jednak w ramach historyczności własnego przekazu.

13 Wersja grecka tekstu ma niezrozumiałą dla czytelnika liczbę mnogą $\pi \rho \circ \varphi \eta ́ \tau \alpha \varsigma$, chociaż dalej będzie mowa już tylko o jednym Bożym wysłanniku. 
oświadczył jednak, że Bóg postanowił już zgubę króla, ponieważ

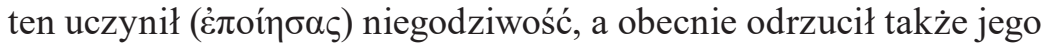
radę $(25,16)$.

Podobny los czeka niewiernego Bogu arcykapłana z Pierwszej Księgi Machabejskiej. Związanie się Jonatana z Demetriuszem przez pakt polityczny, zwłaszcza zaś umieszczenie odpisu traktatu na świętej górze Boga, zostało ocenione przez autora Pierwszej Księgi Machabejskiej jako zło takiej rangi, jak wprowadzenie bożków pogańskich do kraju przez Amazjasza. Szczególnej wagi nabiera w tym kontekście zdanie proroka o pogańskich bożkach czczonych przez króla po zwycięstwie, mimo że przecież nie uratowały one swych ludów przed klęską poniesioną z ręki Amazjasza (2Krn 25,15). Takie działanie wydaje się wprost niedorzeczne! Tak samo absurdalne jest według autora Pierwszej Księgi Machabejskiej zawieranie aliansów przez arcykapłana z kimś, kto nie wybawi jego ludu, a wręcz przeciwnie, będzie czyhał na jego zgubę. Widać więc, że, jak zauważa natchniony autor, Jonatan, rządząc ludem, odszedł już od wierności Bogu i to wcześniej niż niegdyś król judzki.

Poza paralelnym słownictwem ${ }^{14}$ oba passusy 2 Krn 25 i 1 Mch 11 łączy także podobieństwo postaci stojących na czele społeczności narodu wybranego, próba zastępowania pomocy Boga aliansami

14 Z teologicznego punktu widzenia połączenie obu czasowników, występujące także w 1 Krn 22,12, może mieć wpływ na głębsze rozumienie prezentowanego tekstu Pierwszej Księgi Machabejskiej. Werset ów (1Krn 22,12) zawiera życzenie Dawida pod adresem Salomona o użyczenie $(\delta \omega ́ \eta)$ roztropności i rozsądku dla czynienia ( $\pi$ oıє̃̃v) prawa Bożego. Tekst 1Krn 29,19 zawiera podobne w treści błaganie Dawida

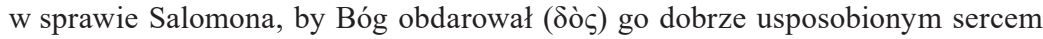
w celu wypełnienia ( $\pi$ oıє̇̃v) przykazań. Dokładnie tego samego potrzebuje obecnie Jonatan we właściwym spełnianiu swych rządów nad ludem. Z kolei w 2Krn 9,8 odnajdujemy zapis o zachwycie, jaki w pogańskiej królowej wzbudziła mądrość Salomona. Wyraziła go ona stwierdzeniem, że to Bóg Izraela jest źródłem owej

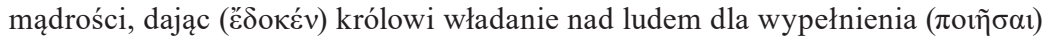
prawa i sprawiedliwości. Jeśli hagiograf nawiązywał także do tych tekstów, to oboma czasownikami zamierzał wyrazić tezę o rządzeniu ludem jako Bożym darze $(\delta i \delta \omega \mu \imath)$ dla króla, jednak dar ów otrzymuje władca w celu czynienia ( $\pi$ oté $\omega)$ woli Boga, nie własnej. Również dla Jonatana jest to imperatyw pierwszorzędnej wagi. 
ludzkimi ${ }^{15}$ oraz postulat odcięcia się od oferowanych, a niepotrzebnych propozycji kompromisu z obcymi.

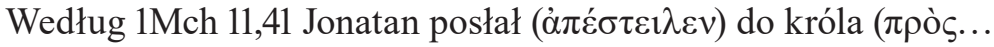

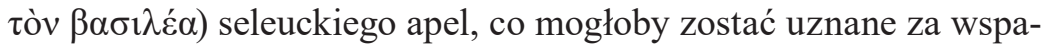
niałe osiągnięcie. Tymczasem zgodnie z całością swej teologii wydarzeń, hagiograf odwołuje się obecnie do passusu 2Krn 25,17-19, w którym (w w. 17) opisuje nieprzemyślaną i pełną pychy decyzję Amazjasza, który po zwycięstwie nad Edomitami chciał natychmiast

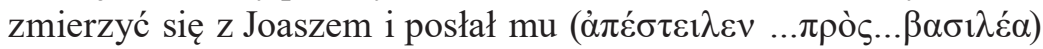
wyzwanie. W zachowaniu króla przejawia się ewidentna próba dowartościowania siebie i własnych możliwości w starciu z przeciwnikiem potężniejszym niż Edomici. ${ }^{16}$ Władca królestwa północnego ostrzegał zaś Amazjasza, że nie zawsze jedno zwycięstwo gwarantuje drugie i łatwo można polec w walce, którą niemądrze się wywołało (w. 18-19). ${ }^{17}$

Podobnie autor Pierwszej Księgi Machabejskiej opowiada o Jonatanie, który posłał swe żądanie do króla seleuckiego. Hagiograf

Wspólne występowanie obu czasowników w pojedynczym wersecie odnajdujemy w Septuagincie bardzo często, bo aż 212 razy. Nigdzie jednak nie da się zauważyć tak bliskiego i uzasadnionego związku teologicznego między 1Mch 11,37 a księgami protokanonicznymi, jak właśnie w powyższej relacji 2Krn 25.

15 Niewykluczone bowiem, że wprowadzenie kultu obcych bożków przez Amazjasza mogło mieć praktyczny cel w ustanowieniu jakiegoś rodzaju paktu o nieagresji między oboma społecznościami. Takie praktyki, choć znacznie później stosowane były w imperiach helleńskich dla zapewnienia sobie spokoju społecznego wieloetnicznych monarchii.

16 Oznacza to również zakwestionowanie Bożej pomocy w walce króla Judy z południowym sąsiadem, por. W. G u s t a f s o n, 2 Chronicles, w: W.S. S t e v e y, D.E. We s t (red.), What the Bible teaches, Ritchie Old Testament Commentaries, Kilmarnock 2013, s. 522. Jest to tym bardziej godne potępienia, że w całościowym zamyśle Kronikarza władcy Izraela i Judy mają stałą możliwość poprawy własnego postępowania i umocnienia się w wierności, por. S.W. H a h n, The Kingdom of God as Liturgical Empire: A Theological Commentary on 1-2 Chronicles, Grand Rapids 2012, s. 93.

17 Nie ma wątpliwości, że odpowiedź króla izraelskiego rozumiana jest przez autora natchnionego jako czyniona w imieniu samego Boga, por. E. B e n Z v i, History, Literature and Theology in the Book of Chronicles, s. 64. 
oczywiście nie krytykuje słuszności opuszczenia zamku przez pogan i odszczepieńców żydowskich, lecz gani pychę, jaka temu towarzyszyła i pewność, że Bóg popiera każde zamierzenie arcykapłana, podobnie jak to było w przypadku króla Amazjasza. Żądanie wycofania się pogan z zamku ukazuje kierunek działań zmierzających do powiększania doczesnych wpływów Jonatana w swym narodzie i przejmowania przez arcykapłana coraz większych prerogatyw królewskich. W myśl Prawa Mojżeszowego nie miały one wchodzić w kompetencje duchowego zwierzchnika narodu.

Uzasadniony związek z taką a nie inną polityką Jonatana zachodzi także w końcowej wzmiance autora Pierwszej Księgi Machabejskiej o Demetriuszu, któremu arcykapłan początkowo zaufał, później jednak został przez seleuckiego władcę zdradzony. Demetriusz nie tylko wykorzystał żołnierzy Jonatana w walce przeciw mieszkańcom własnej stolicy, lecz ponadto, gdy w monarchii nastał już pokój, złamał wszystkie wcześniejsze przyrzeczenia i zobowiązania złożone wobec Judei (1Mch 11, 42-53). Wkrótce powrócił jednak Tryfon, nowy pretendent do korony imperium, i Demetriusz pierzchnął ( $(\mathcal{\varphi} \varphi v \gamma \varepsilon v)$

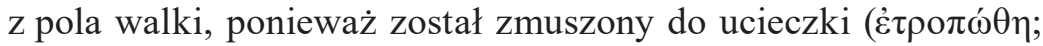
1Mch 11, 55). ${ }^{18}$ Tym samym hagiograf ocenił politykę arcykapłana, który związał się traktatem politycznym z niegodnym zaufania pogańskim władcą, jako błąd i źródło potężnego rozczarowania. Relacjonując wypadki, przyrównał kolejny raz porażkę militarną Demetriusza do batalii Amazjasza z Drugiej Księgi Kronik, którego wojska zostały rozbite przez Joasza, króla Izraela. Pyszny i zadufany w sobie władca Judy, Amazjasz, został zmuszony do ucieczki i umknął (̇ં

Poza Pierwszą Księgą Machabejską wspólna obecność obu przytoczonych powyżej czasowników występuje w całej Septuagincie tylko w tym jednym tekście łączącym skutki inwazji militarnej

18 Autor Pierwszej Księgi Machabejskiej może tu jednocześnie nawiązywać do wypowiedzi 2Krn 25,8 sygnalizującej zmuszenie przez Boga do ucieczki ( $\rho \circ \pi \omega ́ \sigma \alpha \sigma \theta \alpha \imath)$ z pola walki wszystkich, którzy sprzeciwiają się Jego woli, co sugeruje także $1 \mathrm{Mch} 4,20 ; 5,44 ; 6,5 ; 11,15$, por. także Ps 88,24 (LXX). 
z wcześniejszą apostazją arcykapłana na wzór króla Judy, chociaż w tym przypadku ,apostazję” należy rozumieć nie jako odstąpienie od wiary jako takiej, lecz od wierności postępowaniu, które z niej wynika. ${ }^{19}$ Dlatego jest to bardzo rzadki, może nawet jedyny w Biblii Greckiej przypadek, w którym jedna figura retoryczna Amazjasza łączy dwóch bohaterów, skonfliktowanych ze sobą, potem sprzymierzonych, a następnie znów pozostających w konflikcie: żydowskiego arcykapłana i seleuckiego monarchę. Pierwszy z bohaterów porzucił wierność Prawu Mojżeszowemu, realizując własne zamiary. Drugi porzucił wierność swemu żydowskiemu sprzymierzeńcowi, jako władca niewierzący w Boga Izraela. Obu więc łączy owo odstąpienie od wierności. Hagiograf chce przy okazji zwrócić zapewne uwagę także na to, że zdrada Boga przez niewierność Mu prędzej czy później spotka się z tym samym rodzajem zdrady ze strony partnera politycznego. Skutki niewierności Bogu, prędzej czy później, człowiek odczuje także w tym, jak inni ludzie będą postępować wobec niego. Dlatego wspólne interesy obu rządzących musiały się kiedyś zantagonizować. Obaj bowiem, podobnie jak ich pierwowzór, król judzki z Drugiej Księgi Kronik, ulegli wcześniejszej pokusie pychy na skutek dotychczasowej dobrej passy własnych rządów. Niesławny koniec życia Amazjasza stanowić miał przede wszystkim potężne ostrzeżenie dla arcykapłana, który przyjął podobną politykę, realizując własne zamierzenia, niezgodne z wolą Bożą. Los Demetriusza powinien był natomiast skłonić Jonatana do stanowczego i dogłębnego przemyślenia własnego stanowiska. W przeciwnym przypadku, jak zapowiada autor, koniec arcykapłana będzie taki sam.

Złowieszczo w 1Mch 11, 72 brzmi znów uwaga o zmuszeniu do

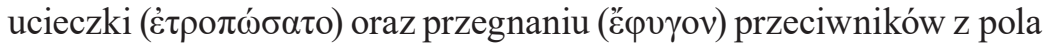
walki przez Jonatana w bitwie pod Chasor, ok. 145 r. przed Chr. Zwykle taka sytuacja powinna prowadzić do wyrażenia wdzięczności Bogu i decyzji o wierności Temu, który takie sukcesy sprawia. Stało

19 Podobnie do 2 Krn 12,2-9; 28,5-7; 33,11 oraz 36,17-18. Por. B.E. K e 11 y, Retribution and Eschatology in Chronicles, The Journal for the Study of the Old Testament, Supplement Series 211, Sheffield 1996, s. 195. 
się prawdopodobnie odwrotnie, na co wskazuje połączenie znanego już czasownika $\tau \rho o \pi o ́ \omega ~ z ~ \varphi \varepsilon v ́ \gamma \omega$, obecne jedynie w analizowanym wyżej wersecie 2 Krn 25, 22. Trzeba tu podkreślić wzmiankę kronikarza, że klęska Amazjasza w wojnie z Joaszem nastąpiła ze zrządzenia Bożego ${ }^{20} \mathrm{i}$ była karą za odrzucenie przez króla rad proroka $(25,16.20)$. Nastąpiło to na skutek zatwardziałości, jaka zrodziła się $\mathrm{W}$ sercu władcy po wygranej bitwie z Edomitami. ${ }^{21} \mathrm{~W}$ przekonaniu Kronikarza to właśnie zwycięstwo stało się początkiem upadku króla Judy. Możliwe więc, że w opinii autora Pierwszej Księgi Machabejskiej, wyrażonej w sposób aluzyjny, kolejny sukces Jonatana nie tylko nie zmienił jego postawy wobec Boga, lecz przeciwnie, zwiększył jego przekonanie, że Bóg go popiera w każdej sytuacji i że droga, którą obrał, jest słuszna. Stało się jednak przeciwnie: chwilowe powodzenie, tak samo jak niegdyś w przypadku Amazjasza, zwiastuje ostateczną klęskę polityki arcykapłana, umocnionego w swej pysze i przekonanego, że jego życie to nieprzerwane pasmo pomyślności. Jonatan nie wyciągnął żadnych wniosków z kłopotów, w jakich się znalazł, gdy paktował z Demetriuszem, oraz z pomocy, jaką Bóg gotów był udzielić mu zawsze, gdyby tylko zechciał słuchać proroka i ukorzyć się przed Bogiem. Wszystkie dotychczasowe oznaki powodzenia posłużyły Jonatanowi do wzmocnienia się we własnym zadufaniu i próżności.

Powyższe przykłady mogą stać się podstawą do sformułowania hipotezy o teologicznym, własnym komentarzu hagiografa Pierwszej Księgi Machabejskiej do poczynań Jonatana. Komentarz ów negatywnie ocenia sukcesy Jonatana, chociaż zrazu wydawać by się mogło,

20 Jako klauzula o charakterze teologicznym, w stylu typowo kronikarskim, por. S. J a p h e t, I and II Chronicles: A Commentary, s. 869.

${ }^{21}$ Werset 16 pozostawia celową ambiwalentność rozumienia działania króla jako nierozwiązaną: decyzja Boga albo jest skutkiem zatwardziałości króla, albo odwrotnie - król postępuje zatwardziale, ponieważ Bóg wcześniej zadecydował o jego zgubie, por. E. B e $\mathrm{n} \mathrm{Z} \mathrm{v} \mathrm{i,} \mathrm{History,} \mathrm{Literature} \mathrm{and} \mathrm{Theology} \mathrm{in} \mathrm{the} \mathrm{Book} \mathrm{of}$ Chronicles, s. 172, przyp. 36. W w. 20, podobnie do oryginału hebrajskiego, grecki

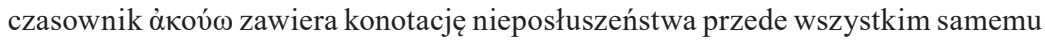
Bogu, por. W. G u s t a f s o n, 2 Chronicles, s. 522-523. 
że sprzyjające arcykapłanowi okoliczności świadczą zarówno o jego wierności Bogu, jak i o błogosławieństwie, jakim może się cieszyć ze strony Boga, dostrzegającego owo poświęcenie dla sprawy ludu. Intencja hagiografa księgi jest dokładnie odwrotna. Autor natchniony rozważa poszczególne przypadki życia arcykapłana na głębszym tle Prawa Mojżeszowego, które Jonatan permanentnie łamie.

Nie jest zatem prawdziwa powszechnie przyjmowana przez historyków i egzegetów opinia, że hagiograf Pierwszej Księgi Machabejskiej jest niemal bezkrytycznym piewcą rodu Machabeuszów.

\section{Przywoływane postaci historyczne z Ksiąg Kronik}

Dokonana wyżej analiza teologiczna życia jednej konkretnej postaci tradycji kronikarskiej odkrywa bardzo szerokie pole badań nad innymi bohaterami historii Izraela, które zostały przywołane przez autora Pierwszej Księgi Machabejskiej. Ograniczone ramy niniejszej pracy nie pozwalają na ich przeprowadzenie. Jednakże pobieżne choćby tylko spojrzenie przekonuje, że żadna z postaci, do których hagiograf nawiązuje w tekście swej księgi, nie jest przez niego traktowana dla siebie, lecz stanowi fundament i tło teologicznej oceny postępowania bohaterów narracji historycznej w Pierwszej Księdze Machabejskiej. Nie chodzi tu zresztą o samą postać, ale bardziej o pewne konkretne sytuacje prezentujące jej postępowanie, zarówno w sensie pozytywnym, jak i negatywnym, w zależności od opisywanego działania bohaterów księgi. Wyszczególnione poniżej postaci z historii Izraela stanowią ważne odniesienie o charakterze pouczającym. Autor Pierwszej Księgi Machabejskiej używa ich, by przekonać czytelnika, że każde wydarzenie lub sytuacja z życia bohaterów jego księgi miały już miejsce wcześniej. Poczynania głównych postaci z Ksiąg Kronik, jak wiele innych ksiąg Starego Testamentu, dostarczają bogatego materiału porównawczego, pozwalając autorowi Pierwszej Księgi Machabejskiej na wielopłaszczyznową ocenę każdego z wodzów powstania machabejskiego. W wyniku całościowej egzegezy tekstu można ustalić następującą tabelę postaci obecnych 
w Księgach Kronik, do których hagiograf Pierwszej Księgi Machabejskiej odniósł się w sposób aluzyjny lub wprost:22

Tab. 1. Postacie z historii Izraela w Księgach Kronik

\begin{tabular}{|l|c|c|c|}
\hline \multicolumn{1}{|c|}{ postaci } & $\begin{array}{c}\text { liczba } \\
\text { nawiązań }\end{array}$ & postaci & $\begin{array}{c}\text { liczba } \\
\text { nawiązań }\end{array}$ \\
\hline patriarchowie & 1 & Atalia & 2 \\
\hline Mojżesz & 1 & Joasz & 8 \\
\hline Saul & 5 & Amazjasz & 11 \\
\hline Dawid & 36 & Azariasz & 4 \\
\hline Joab & 4 & Jotam & 2 \\
\hline Salomon & 17 & Achaz & 2 \\
\hline Roboam & 9 & Ezechiasz & 21 \\
\hline Abiasz & 2 & Manasses & 10 \\
\hline Asa & 22 & Amon & 1 \\
\hline Jozafat & 22 & Jozjasz & 7 \\
\hline Joram & 5 & Jojakim & 3 \\
\hline Ochozjasz & 1 & Sedecjasz & 4 \\
\hline
\end{tabular}

Ukazanie postępowania bohaterów powstania machabejskiego w świetle życia przedstawionych w tabeli postaci historycznych nasuwa dwie ważne z punktu widzenia egzegezy kwestie, które obecnie jedynie sygnalizuję, ponieważ pełne ujęcie tematu wymaga przeprowadzenia szczegółowych analiz egzegetycznych.

Pierwszy problem to ten, gdy hagiograf stosuje terminologię lub całe konstrukcje zdaniowe obecne zarówno w Księgach Samuela,

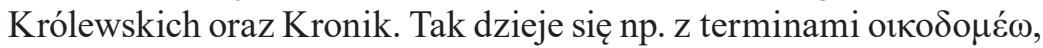

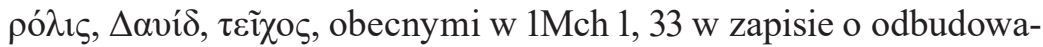
niu murów Jerozolimy przez pogan. Mogły one zostać zaczerpnięte

22 Każda z postaci, do których nawiązuje autor Pierwszej Księgi Machabejskiej, choć bardzo skrótowo, została omówiona w sposób podobny do postępowania Amazjasza w t. II komentarza, który ukaże się w ramach Nowego Komentarza Biblijnego. 
zarówno z 1Krl 5, 14 $\alpha$; 10, 22 $\alpha$, jak i z 2Krn 32, 5 oraz 33, $14 .{ }^{23}$ Trudno wyrokować, którymi tekstami posiłkował się hagiograf w prezentacji swych bohaterów, skoro we wszystkich czterech budowniczymi murów miasta Dawidowego są królowie Judy: Salomon (1Krl 5, 14 $\alpha ; 10$, $22 \alpha$ ), Ezechiasz (2Krn 32, 5) oraz Manasses (2Krn 33, 14). Aluzja do każdej z tych postaci jest więc możliwa, lecz w sensie prawdopodobnie odwrotnym, to znaczy: prawo do budowania obwarowań miasta Bożego ma tylko ten władca Izraela, który jest wierny Bogu. ${ }^{24}$ Skoro zatem obecnie mury miasta budują poganie, wniosek nasuwa się samoistnie, że, w przekonaniu hagiografa, Żydzi zgrzeszyli niewiernością wobec Boga. I podobnie jak w dziejach Izraela wznoszenie murów miasta świętego oznaczało zawsze czasy prosperity, czasy opieki Bożej rozciągniętej nad ludem z racji zachowywanej przez Izraelitów wierności Bogu, tak samo (lecz ze znakiem przeciwnym) w Pierwszej Księdze Machabejskiej budowa obwarowań oznacza nastanie czasu odrywania miasta od narodu, a tym samym opuszczenia go przez boskiego Opiekuna.

Na osobną uwagę zasługuje fakt, że pisarz natchniony wprawdzie zaczerpnął wersety z Pierwszej Księgi Królewskiej, ale z tekstów greckich, rozszerzających zapis hebrajski. Wersetów $5,14 \alpha$ oraz $10,22 \alpha$ nie ma bowiem w wersji hebrajskiej tej księgi. Jeśli przyjąć zatem, że pierwotna wersja Pierwszej Księgi Machabejskiej była także pisana w języku narodu wybranego, jej wersja grecka wydatnie rozszerzałaby teologiczne pole zainteresowania natchnionego autora. To tylko jeden przykład zachęcający do dalszej pogłębionej analizy.

Druga kwestia dotyczy pominięcia przez autora Pierwszej Księgi Machabejskiej tekstów Ksiąg Samuela i Królewskich i odwołanie się

23 W pierwszym, wydanym już tomie mojego komentarza do Pierwszej Księgi Machabejskiej, przy okazji omówienia tych właśnie tekstów ów problem nie został poruszony. zob. J. N a w r o t, Pierwsza Księga Machabejska-rozdziały 1, 1-6,16, s. 366.

24 Por. m.in. 1Mch 4,60; 6,7 oraz 2Krn 8,5; 14,6; Ezd 4,12.16; Ne 3,13; 4,4.11; 7,1; Tb 13,17; Ps 51,20. W Iz 60,10 kontekst odbudowy murów miasta przez cudzoziemców jest zupełnie odwrotny niż w Pierwszej Księgi Machabejskiej, dlatego nie może on stać się odniesieniem do omawianego wersetu księgi. 
wyłącznie do tekstów Ksiąg Kronik. Passus 2Krn 25, 1-28 zawiera wersety 5-16, nieobecne w relacji tych samych zdarzeń autora $2 \mathrm{Krl} 14$, 1-20. Wiele innych terminów oraz konstrukcji zdaniowych obecnych w tekście Pierwszej Księgi Machabejskiej nie ma odpowiedników w Księgach Samuela i Królewskich, lecz wyłącznie w dziele kroni-

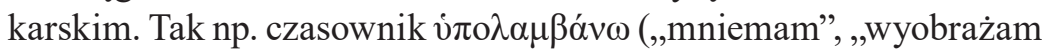
sobie”, „myślę”, „suponuję”), przywołujący zamysły Antiocha IV w 1Mch 1, 16, odsyła zapewne czytelnika do jedynego w Biblii wersetu, w którym to słowo również występuje, czyli do $2 \mathrm{Krn} 25,8 .{ }^{25}$ Zestawienie obu wypowiedzi bardzo dobrze wpisuje się w ogólny zamysł teologiczny autora Pierwszej Księgi Machabejskiej, który przyjmuje, że Bóg Izraela kieruje nie tylko dziejami własnego ludu, lecz także postępowaniem władców pogańskich. Dlatego poczynania króla seleuckiego, jeśli dochodzą do skutku, spełniają się dzięki chwilowemu wsparciu ich przez Boga. Podobnie sens zwrotu ह̌ $\pi \varepsilon \sigma o v$

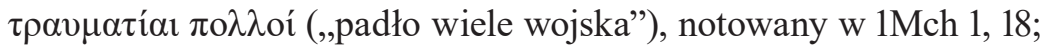
3,$11 ; 8,10 ; 9,17.40$ oraz 16, 8, można lepiej zrozumieć w zestawieniu z 2 Krn 5, 22, na co wskazuje podobny kontekst militarny oraz fakt, że niemal zawsze chodzi o żołnierzy cudzoziemskich. ${ }^{26}$

Werset zapisany przez narratora Pierwszej Księgi Machabejskiej ukazuje zatem właściwą perspektywę teologiczną: chodzi o wojnę Bożą. Wszędzie tam, gdzie padają żołnierze pogańscy w walce z powstańcami, sam Bóg wspiera swój lud i jego przywódców. Podobnie

25 Chodzi oczywiście o występowanie tego słowa w narracjach historycznych. Czasownik ów występuje bowiem w Septuagincie 56 razy, lecz poza apokryfami niemal wyłącznie w tekstach poetyckich lub mądrościowych. Za najbliższy treści wersetu Pierwszej Księgi Machabejskiej można by uznać werset Jr 44,9 (LXX), lecz całkowicie różny kontekst historyczno-teologiczny wyklucza raczej tę paralelę.

26 1Mch 9,17 obok pogan obejmuje tą konstrukcją także żołnierzy Judy Machabeusza. Z racji wyróżnienia jednak zabitych w boju pogan, jako punkt odniesienia należy wykluczyć werset Sdz 9,20 (opowiadający o walce wewnątrz Izraela). Z kolei tekst Dn 11,26, zawierający analizowany tu zwrot użyty także w sensie militarnym, jest również wątpliwy jako aluzyjny kontekst dla autora Pierwszej Księgi Machabejskiej, z powodu zbyt bliskiego czasu powstania obu dzieł natchnionych, tym bardziej, że chodzi dodatkowo o wersję grecką Księgi Daniela, jeszcze późniejszą niż oryginał hebrajski. 


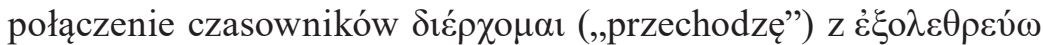
(,niszczę”, „wytracam”, „tępię”) w opisie dokonań Judy Machabeusza w 1Mch 3, 8 zestawić można wyłącznie z jego odpowiednikiem w 2Krn 20,10, stanowiącym część modlitwy króla judzkiego, Jozafata, w świątyni (w. 6-12). ${ }^{27}$ Werset 10 zawiera skargę władcy przed Bogiem na postępowanie pogańskich wrogów, oszczędzonych niegdyś przez Izraelitów wracających z niewoli egipskiej, a obecnie próbujących siłą odebrać dziedzictwo ziemi narodowi wybranemu. To więc, co wówczas z rozkazu Bożego nie zostało wykonane, spełni się obecnie w bohaterskiej walce Judy i jego żołnierzy lub też może stanowić wartościowy komentarz uzasadniający konieczność walk bohatera. Może to być albo realizacja starożytnych nakazów wytępienia zagrażających wierze Izraelitów pogan, albo powielenie takiego działania $\mathrm{w}$ życiu wielkich postaci historii Izraela. ${ }^{28}$ Także w tym przypadku zwycięstwa powstańców należy bezpośrednio przypisać Bogu, jako inicjatorowi wszelkich ludzkich sukcesów. ${ }^{29}$

Trzy powyższe przykłady pozwalają bardziej uświadomić sobie wielopłaszczyznowość koncepcji teologicznej, która przyświecała pisarzowi natchnionemu, gdy powziął decyzję napisania swego dzieła. Geniusz hagiografa daje się poznać właśnie przez całkowitą zgodność teologiczną w ustanowieniu poszczególnych związków wyrazowych. W połączeniu z suponowaną, doskonałą znajomością tekstów biblijnych przez autora Pierwszej Księgi Machabejskiej ${ }^{30}$

27 Oba czasowniki znaleźć można jeszcze w $1 \mathrm{Krl}$ 18,5, lecz werset ten dotyczy zupełnie innej sprawy i okoliczności. Ten kierunek analizy nie został również ujęty w wydanym już drukiem komentarzu. Zob. J. N a w r o t, Pierwsza Księga Machabejska - rozdziały 1, 1-6,16, s. 566.

28 Czasownik $\dot{\varepsilon} \xi o \lambda \varepsilon \theta \rho \varepsilon v ́ \omega$ w tym kontekście, por. np. Pwt 2,34; 3,6; 4,38; 7,17.23-24, 9,3-5, 12,29.30, 18,12, 31,3-4.19; Joz 2,10; 9,24; 10,28.32.37; Sdz 1,17; 4,24; $1 \mathrm{Sm} 15,3$, itd.

29 Odwrotnie niż w 2Krn 20,10, gdzie Jozafat ma świadomość, że bez Bożej pomocy jest bezradny wobec inwazji, Juda może jednak cieszyć się pełnią wsparcia ze strony Boga. Por. także J. A. T h o m p s o n, 1-2 Chronicles. An Exegetical and Theological Exposition of Holy Scripture, New American Commentary 9, s. 294.

30 W tym względzie pomocna jest lektura m.in. artykułu J. N. L i g h t st o n e, Late Second Temple Judaism: A Recontruction and Re-description as 
może to świadczyć o boskim natchnieniu towarzyszącym mu w trakcie opracowywania materiału księgi.

\section{Teologia Ksiąg Kronik a Pierwsza Księga Machabejska}

Księgi Kronik nie są ani jedynym, ani dominującym punktem odniesienia dla teologii Pierwszej Księgi Machabejskiej. Przywołuję je w niniejszej pracy jedynie jako pewien określony element tła teologicznej oceny opisywanych zdarzeń powstania machabejskiego. Jest to zatem tylko wąska egzemplifikacja całości projektu pisarza biblijnego. Może warto tu również nadmienić, że problemem sposobu zapożyczania tekstów natchnionych w Pierwszej Księdze Machabejskiej zamierzam zająć się w osobnej pracy. ${ }^{31}$

Ponieważ wszystkie księgi biblijne stanowią jeden korpus słowa Bożego i są częścią całego orędzia biblijnego, należy zatem postawić następujące pytania: Co Księgi Kronik wnoszą w teologię Pierwszej Księgi Machabejskiej? Jaki jest ich wpływ na postrzeganie powstania machabejskiego przez hagiografa? W czym ich teologia okazuje się przydatna do budowania narracji autora?

Na potrzeby niniejszego artykułu postaram się odpowiedzieć na powyższe pytania syntetycznie. W mojej pracy nad Pierwszą Księgą Machabejską przyjęte tu stanowisko badawcze służy mi jednak za punkt wyjścia do pogłębionych analiz, które w przyszłości zamierzam poczynić.

a Religio-Cultural System, w: A. D a m m (red.), Religions and Education in Antiquity: Studies in Honour of Michel Desjardins, Leiden-Boston 2019, s. 76-106 oraz B. M. J a c o b s, Y. S h e m - T o v, History: Issues in the Teaching and Learning of Jewish History, w: H. M i 11 e r, L. D. G r a n t, A. P o m s o n, International Handbook of Jewish Education, cz. 1, Heidelberg-London-New York, s. 441-460. Resumé sposobu nauczania Biblii w starożytnym Izraelu znaleźć można np. w: E. F e r g u s o n, Backgrounds of Early Christianity, Grand Rapids 2003, s. 112-113.

${ }_{31}$ Aby poprawnie zrozumieć moją intencję w tym punkcie, ważna jest świadomość czytelnika, że niniejszy artykuł wyprzedza edycję drugiego tomu mojego komentarza do Pierwszej Księgi Machabejskiej w ramach serii Nowy Komentarz Biblijny; zob. przyp. 4. 
Stosowane w księdze aluzje do dawniejszych ksiąg biblijnych stoją w służbie teologii prezentowanych wydarzeń. Zapożyczenia te uwidaczniają się w formie dwu lub trzech terminów (lub nawet całych wyrażeń i zdaniowych konstrukcji) celowo ze sobą zestawionych ${ }^{32}$ przez autora natchnionego, by nakierować czytelnika na konkretny werset wcześniejszej księgi biblijnej. Nie wydaje się, że są to jedynie zbiegi okoliczności wynikające z przypadkowego przejmowania terminologii z dawniejszych, analogicznych kontekstów. Można by tę wątpliwość sformułować, gdyby chodziło o jednostkowy lub rzadki kazus. W omawianej księdze autor natchniony używa jednakże owych zapożyczeń w formie aluzji niemal we wszystkich zdaniach.

Jak w każdej księdze biblijnej, także tutaj najważniejszy jest przekaz teologiczny autora Pierwszej Księgi Machabejskiej, usprawiedliwiający taką właśnie metodę egzegezy użytą w niniejszej pracy, nie zaś sama historyczność relacjonowanych wydarzeń, chociaż tej nie sposób kwestionować, skoro autor opisuje rzeczywiste fakty z czasów powstania Machabeuszy. Dobór odpowiedniego słownictwa oraz zastosowanie składni zdaniowej obecnej w wersetach ksiąg protokanonicznych nie przeszkadza w niczym historyczności przekazu hagiografa opisującego poszczególne sylwetki przywódców powstania. Autor sam mógł być przecież świadkiem spisywanych zdarzeń lub przygotowywać swoją relację na podstawie przekazów tworzonych bezpośrednio po nich. Umiał on natomiast bezbłędnie korzystać ze wszystkich ksiąg protokanonicznych Starego Testamentu, by budować w poszczególnych wersetach własną narrację. Jest ona zarówno spójna, jak i dopełnia się przez nieustanne używanie terminów z różnych ksiąg, odnoszących się do rozmaitych sytuacji

32 Nie chodzi o pełne cytowanie wersetów innych ksiąg (co ma miejsce zwłaszcza w relacji Nowego Testamentu do Starego), lecz zamieszczenie jedynie fragmentu wypowiedzi wcześniejszych autorów biblijnych, niekiedy zaledwie jednego lub kilku słów, które hagiograf uznał za konieczne w celu przeprowadzenia własnej myśli teologicznej opartej na istniejącej już tradycji narracyjnej. Warto jednak zaznaczyć, że pełne cytowanie tekstów nie jest w księdze zupełnie nieobecne, czego przykładem jest choćby $1 \mathrm{Mch} 7,17$, niemal dosłownie przytaczający słownictwo Ps 79,2-3. 
z minionej historii Izraela. Te aluzyjne odwołania dobrze do siebie pasują i nie burzą toku narracji. Tworzą one we wszystkich wersetach, a przez to w całości księgi, doskonale zharmonizowany, jeden przekaz teologiczny. Można zgodzić się zatem z tezą, że jest to najważniejsze znamię oryginalności orędzia teologicznego Pierwszej Księgi Machabejskiej. Zapisane fakty życia bohaterów zostały zinterpretowane w pełnej zgodności z duchem narracji biblijnej.

Poza arcykapłanem Szymonem, przynajmniej w początkowym etapie swej działalności, każdy z przywódców powstania machabejskiego pozostaje wierny Bogu Izraela i postępuje ściśle według Prawa Mojżeszowego, choć później, niestety, ulega to radykalnej zmianie. Teologicznie całość ich życia ukazana została właśnie poprzez zbieżność z postępowaniem głównych postaci z minionej historii Izraela. Bohaterowie Pierwszej Księgi Machabejskiej działają zatem albo podobnie do przywoływanych aluzyjnie postaci z historii Izraela, albo postępują dokładnie odwrotnie. Odpowiednio zatem czyny bohaterów księgi spotykają się bądź z Bożą aprobatą, jako wsparcie dla ich postanowień i działań, bądź - w przypadku niewierności - Bóg sprzeciwia się ich działaniom. Zauważamy zatem, że gdy następuje odejście wodzów powstania od wierności Bogu, przymierzu i prawu, bohaterowie narracji autora księgi jawią się jako odwrotność postępowania dawnych mężów Izraela. Dotyczy to zwłaszcza Judy Machabeusza i Jonatana, jego brata i następcy. Dokonując czynów przeciwnych do tych, które znane są z opowiadań o przeszłości, bohaterowie owi stają w opozycji do przedsięwzięć wodzów powstania. Szczególnie wyraźnie jawi się ów etap w odniesieniu do wydarzeń z życia postaci z wczesnej historii Izraela, to jest na przykład: Abrahama (Rdz 14,14 i 1Mch 10,78), Mojżesza (Pwt 1,29 i 1Mch 12,28), Jozuego (Joz 8,18-19; Syr 46, 2 i 1Mch 6,25), sędziów (Sdz Sdz 4,4.10.14 i 1Mch 10,74), Samuela (1Sm 15,11 i 1Mch 12,27), Dawida (1Sm 17,5 i 1Mch 6,35), lub wiernych Bogu niektórych, późniejszych królów Judy, jak Asa (1Krl 15,8 i 1Mch 1,54) czy Jozjasz (2Krn 35,21-22 i 1Mch 9,17). Wydaje się, że zawarta w niniejszej pracy tabela postaci z Ksiąg Kronik obrazuje to (na zasadnie przykładu) w sposób wystarczający. 
Dobrym przykładem jest tu także przywołany powyżej arcykapłan Szymon. Zdumiewająco wręcz - na przekór bowiem oficjalnej wymowie treści zapisu - został on przez samego autora oceniony jako odwrotność bohatera pozytywnego niemal w całości swych rządów! W przekonaniu hagiografa w działalności pełniącego urząd wodza powstania - ostatniego z Machabeuszów - nie pojawia się już w ogóle etap wierności Bogu. Może to zadziwiać, zwłaszcza gdy czyta się zawartą w 1Mch 14,25-45 wielką jego eulogię. Została ona jednak w księdze tak skomponowana, by odzwierciedlała tyleż powszechne, ile bezrefleksyjne przekonanie ludu o jego wielkości i wierności prawu. Teologiczna ocena hagiografa jest wyraźnie nieprzychylna arcykapłanowi, choć doskonale wyważona, a w tonie spokojna.

Zapis księgi przywołuje, choć nie z imienia, również znane z historii Izraela postaci negatywne, które sprzeniewierzyły się urzędowi królewskiemu lub nie wykazały dostatecznej wierności Bogu. Dla przykładu są to: Saul (1Krn 10,6-8 i 1Mch 11,74), Salomon (1Krn 29,19 i 1Mch 11,33), Roboam (2Krn 11,11 i 1Mch 13,10), Achaz (2Krn 28,21 i $1 \mathrm{Mch} 11,47)$, Ezechiasz (2Krn 32,25 i 1Mch 11,53), Manasses (2Krn 33,9 i 1Mch 13,41), Jojakim (2Krn 36,5 $\delta$ i 1Mch 1,37) oraz Sedecjasz (2Krn 36,11-21 i 1Mch 13,36). Poszczególne epizody ich życia stały się podłożem opisu wszelkiego rodzaju niewierności Bożym nakazom w przypadku bohaterów powstania. Autor zachęca, by przez porównanie z tymi postaciami czytelnik wyrobił sobie właściwą ocenę działań przywódców insurekcji machabejskiej.

Jak przyjdzie nam to niejednokrotnie ukazać w toku przyszłych, konkretnych analiz egzegetycznych, oryginalny rys kompozycyjny księgi polega również na fakcie, że często w jednej wypowiedzi autor korzysta z wcześniej sformułowanych przez innych autorów biblijnych wersetów dotyczących zupełnie różnych postaci, wydarzeń i czasów, w jakich one żyją i działają, a także odnosić się do rozmaitych nurtów i tradycji literackich Starego Testamentu. Co niejednokrotnie zdumiewa uważnego badacza tekstu, w wyniku badań widać wyraźnie, że dobór tych tekstów jest tak precyzyjny, iż nigdzie nie zachodzą jakiekolwiek teologiczne sprzeczności między 
pierwowzorami, do których autor się odnosi a jego własną teologiczną intencją. Można to zauważyć zwłaszcza tam, gdzie w jednym wersecie hagiograf czyni aluzje do kilku zupełnie odrębnych tekstów wcześniejszych pism biblijnych, należących do różnych nurtów biblijnych. Dotyczy to, jak już wspominałem, nie tylko Ksiąg Kronik, lecz wydaje się stałą zasadą interpretowania przez autora natchnionego wcześniejszych tekstów biblijnych w całym jego dziele.

Jednym z ogromnej liczby przykładów takiego podejścia może być werset $1 \mathrm{Mch} 6,23$, w którym połączenie czasowników $\delta o v \lambda \varepsilon v ́ \omega$

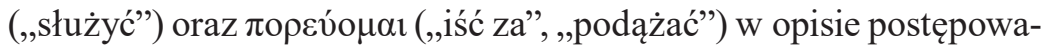
nia zdrajców żydowskich przywołuje wiele wcześniejszych tekstów, krzyżując różne płaszczyzny funkcjonowania tych terminów. I tak przykładowo w świetle aluzyjnie powołanego w Pierwszej Księgi Machabejskiej fragmentu 1Krl 16,31 i 26,19 mamy zabieg porównania postaw; w świetle Jr 2,20; 13,10 jest to oskarżenie; aluzja do 1Sm 12,14; Jr 25,6 i 42,15 ukazuje postawę odszczepieńców stanowiącą zarazem postulat przemiany życia; wreszcie odniesienie do Wj 14,12 i 1Sm 16,16-19 to wspomnienie historyczne postaw Izraelitów podobnych do tych, jakimi w czasach Machabeuszy cechują się niewierni prawu Żydzi. ${ }^{33}$

Ponieważ Pierwsza Księga Machabejska należy do corpus biblicum, oczywiste jest, że to Bóg kieruje wszystkimi wydarzeniami zgodnie ze swym zamierzeniem, zarówno popierając dążenia bohaterów, jak i sprzeciwiając się im. Jest tak, chociaż w tej księdze nigdy Bóg, jako taki, nie został ujawniony wprost jako strona czynnie powodująca jakieś wydarzenie lub jego skutki. Autor co najwyżej wspomina o Bogu w sposób zawoalowany, lecz nigdy nie oddaje Mu głosu, a Bóg ani razu nie wpływa bezpośrednio na ten czy inny epizod powstania machabejskiego. Przyjęty przez autora Pierwszej Księgi Machabejskiej styl prezentacji literackiej zbliża narrację tej księgi do mądrościowego opowiadania Rdz 37-50, w którym Bóg

33 Bardziej szczegółowa analiza wszystkich tekstów pojawi się w przygotowywanym drugim tomie komentarza; zob. przyp. 4 i 29. 
jakby zza kurtyny decyduje o losach głównego bohatera. ${ }^{34}$ Ten sam styl narracji odnajdujemy w Księdze Estery czy Księdze Tobiasza, gdzie również brakuje bezpośrednio ukazanych działań Boga (co z kolei dominuje w narracji ksiąg protokanonicznych).

Taki sposób prowadzenia narracji łączy się ściśle z postulatem pisania historii jako magistra vitae. Czytelnik jest postawiony wobec zawartego implicite $\mathrm{w}$ tekście postulatu, by nie powielać błędów wcześniejszych władców Izraela i Judy. Postulat ten wpisuje się doskonale w całość orędzia biblijnego, lecz w Pierwszej Księsze Machabejskiej nabiera szczególnej wagi. Jest tak dlatego, że w czasach Machabeuszy brakuje proroków, którzy w imieniu Boga napominaliby przywódców powstania i sprzeciwiali się narastającej i niedającej się powstrzymać niewierności Bogu Izraela, która charakteryzuje zarówno przywódców, jak i cały lud. W tej sytuacji przemawiają same dzieje narodu wybranego, ukazane przez autora Pierwszej Księgi Machabejskiej jako tło opisywanych wydarzeń i źródło wymogów działania zgodnego z Prawem Mojżeszowym.

Przynależność Pierwszej Księgi Machabejskiej do nurtu historycznego Starego Testamentu wydaje się faworyzować w księdze deuteronomistyczną ocenę dziejów Izraela. To właśnie wierność Prawu Mojżeszowemu decyduje o sukcesie podejmowanych przez przywódców powstania działań i doprowadzeniu ich do pozytywnego końca. W tym kontekście nurt deuteronomistyczny w Starym Testamencie okazuje się nie tylko literackim podejściem pisarzy natchnionych do historii opisanej w księgach protokanonicznych, lecz także podstawowym, natchnionym, choć nie jedynym, sposobem oceniania całości dziejów narodu wybranego.

34 U. Rappaport mówi w tym kontekście o Bogu ,jako «reżyserze spektaklu», który realizuje swoje plany poprzez ludzi. Ich odwaga lub tchórzostwo, mądrość lub głupota, zaufanie do Boga lub arogancja są rezultatem określonego Boskiego programu lub intencji. Ale to dzięki ludziom Bóg osiąga swoje cele a nie poprzez cuda, anioły czy jakąkolwiek siłę metafizyczną". Cyt. za: U. R a p p a p o r t, $A$ Note on the Use of the Bible in 1 Maccabees, s. 175. 
Prorocka lub mądrościowa ocena historii narodu wybranego pozostaje także w kręgu zainteresowania hagiografa, skoro w Pierwszej Księgi Machabejskiej odnaleźć można bardzo liczne odniesienia do ksiąg prorockich i (choć w nieco mniejszym stopniu) także do mądrościowych. Do tych ostatnich autor odwołuje się zwłaszcza tam, gdzie chodzi o swoiste definiowanie działalności bohaterów jego księgi w świetle mądrości lub głupoty (np. Prz 17,4b i 1Mch 7,11). Jedną z cech najbardziej bodaj charakteryzujących podejście autora Pierwszej Księgi Machabejskiej do historii, widzianej w perspektywie teologicznej, jest ukazywanie wydarzeń wyłącznie z perspektywy już dokonanej, to znaczy, że coś już zaistniało jako rzeczywisty fakt. Nigdzie w księdze nie ma boskich zapowiedzi czegoś, co ma dopiero nastąpić. Takie uprzedzające zapowiedzi są typowym zabiegiem narracyjnym autorów natchnionych wcześniejszych ksiąg biblijnych. To właśnie wyraźnie różni Pierwszą Księgę Machabejską od przywoływanych w jej toku pierwowzorów.

Obecność w Pierwszej Księdze Machabejskiej odwołań do Ksiąg Kronik jest koronnym przykładem jedności i spójnego rozwoju teologii tekstu biblijnego. Widać to we odpowiedniej i niesprzecznej reinterpretacji prawd teologicznych w nowych warunkach historycznych, społecznych, religijnych i kulturowych. Niezmienne jednak pozostają (przy zmieniających się okolicznościach i wydarzeniach) fundamenty wiary Izraela. A zatem opisy historyczne Pierwszej Księgi Machabejskiej dopełniają i rozwijają teologiczny sens owego bogactwa minionych sytuacji i warunków, sens obecny już w passusach pisanych przez wcześniejszych autorów. ${ }^{35}$ Także zasada analogii

35 Na przykład analiza tekstów obu Ksiąg Kronik ukazuje nie tylko teologiczny sposób interpretacji i oceny dziejów Izraela w kontekście czasów powygnaniowych, lecz ujawnia także spojrzenie natchnionych autorów w przyszłość powracających z niewoli pokoleń. Miniona niewola ma stać się fundamentem samoświadomości Żydów jako narodu wybranego. Dzieje przed niewolą mają zatem legitymizować obecną wspólnotę, stanowiącą ciągłość z przeszłymi pokoleniami niepodległego państwa. Dotyczy to szczególnie dawnej, hierarchicznej struktury społeczności przedwygnaniowej, która ma uzasadniać trwanie tejże hierarchii także po powrocie z wygnania; przy czym szczególna rola przypadnie tu odnowionej świątyni. 
wiary ukazuje się w przyjętym w tej księdze principium wierności Bogu na tych samych płaszczyznach obecnych we wszystkich księgach: postępowania zgodnego z pierwszym przykazaniem dekalogu, szczerości intencji działania i zaufania do Boga. Są to wartości trwałe i niepodlegające uwarunkowaniom historyczno-kulturowym. Hagiograf potwierdza faktem swego natchnienia słuszność tego właśnie sposobu teologicznej interpretacji tekstów biblijnych. ${ }^{36}$

Każdy egzegeta nie może jednak zapomnieć o ważnym tu zagadnieniu, którego nie sposób pominąć w poprawnie przeprowadzonej analizie. Obecnie mamy do czynienia wyłącznie z greckim tekstem Pierwszej Księgi Machabejskiej, którego natchniony autor również korzystał jedynie z greckiego tłumaczenia tekstów natchnionych, a mianowicie z Septuaginty. Niemożliwe już dziś jest przebadanie zaginionego oryginału hebrajskiego Pierwszej Księgi Machabejskiej. Dlatego tak niezwykle istotny jest fakt, że hagiograf korzystał właśnie z Biblii Greckiej, także w swoich aluzyjnych odwołaniach do innych ksiąg, i to jej zapis interpretuje. ${ }^{37}$ Wyjaśnienie relacji między tekstem hebrajskim a greckim Pisma Świętego ma głębokie znaczenie do zrozumienia sposobu, w jaki autor Pierwszej Księgi Machabejskiej korzystał z wcześniejszych tekstów, również natchnionych i to niezależnie od stopnia wierności poszczególnych ksiąg Septuaginty jej hebrajskiemu oryginałowi. Za każdym razem trzeba wziąć bowiem

Nadrzędną rolę odgrywać ma teokracja, w której Bóg znów - jak za dawnych czasów - stanie się właściwym Królem narodu; por. J. E. D y c k, The Theocratic Ideology of the Chronicler, Leiden-Boston-Köln 1998, passim.

$36 \mathrm{~W}$ tej materii por. m. in. J. F. J o h n s o n, Analogia fidei as Hermeneutical Principle, Springfielder 36/1972-1973, s. 249-259; W. C. K a i s e r Jr., Toward an Exegetical Theology: Biblical Exegesis for Preaching and Teaching, Grand Rapids 1981, s. 69-184, zwł. s. 131-148.

37 Równie niemożliwa jest odpowiedź, czy autor wersji hebrajskiej korzystał w ten sam sposób z materiału ksiąg protokanonicznych, co autor wersji greckiej. W 2004 r. w Jerozolimie ukazało się tłumaczenie hebrajskie Pierwszej Księgi Machabejskiej dokonane przez U. R a p p a p o r t a: The First Book of Maccabees: Introduction, Hebrew Translation and Commentary. Mimo niewątpliwej wartości tej próby rekonstrukcji pierwotnego tekstu, trudno cokolwiek wyrokować o jego wartości jako źródła analiz egzegetycznych. 
pod uwagę nie tylko samo brzmienie tekstu, lecz także teologię, z której wyrasta, a ta w okresie tworzenia Septuaginty była całkiem różna od całościowego milieu zapisów hebrajskich.

Już nieco poza ramami wyznaczonymi przez tytuł niniejszego artykułu zapytać można też o kierunek odwrotny: Co Pierwsza Księga Machabejska wnosi w rozumienie teologii dawniejszych ksiąg biblijnych? Trzeba uświadomić sobie wpierw zasadność takiego kierunku myślenia. Wiadomo przecież, że rozwój teologii w Biblii dokonuje się wyłącznie zgodnie ze zwrotem osi czasu, dla chrześcijan skierowanym ku swemu wypełnieniu w Jezusie Chrystusie. Jednak uzasadnione wydają się następujące pytania: W jaki sposób autorzy natchnieni późniejszych ksiąg Starego Testamentu patrzyli na dzieła wcześniejsze? Jakim pryncypiom w księgach protokanonicznych nadawali priorytet? Czy ich ocena starszych tekstów może być reprezentatywna dla późniejszego okresu rozwoju teologii Pisma, czy każdy ma własną specyfikę, zależną od opracowywanego przez siebie materiału? I wreszcie: Czy istnieje coś, co obok wypełnienia w Jezusie Chrystusie może stać się fundamentem i celem rozwoju teologii biblijnej? Jak w te zagadnienia wpisuje się teologia głównego, interesującego nas dzieła biblijnego?

Nie są to z pewnością wszystkie pytania, jakie można postawić temu kierunkowi interpretacji wewnątrzbiblijnej, lecz przed podjęciem badań mogą one stać się pomocne w odszukaniu właściwego kierunku poszukiwań. Autor niniejszej pracy nie jest w stanie odpowiedzieć w pełni i przekonująco na postawione przez siebie pytania. Badania w tym kierunku nie zostały, jak się wydaje, jeszcze podjęte ani w polskiej, ani może nawet w światowej egzegezie. W każdym razie moje poszukiwania odpowiednich prac nie przyniosły dotychczas zadowalających rezultatów.

Powyższe uwagi odkrywają wartość badań, które prowadzone wprawdzie jedynie w obszarze Pierwszej Księgi Machabejskiej zarysowują jednak ogromne pole nowatorskich analiz zwłaszcza na płaszczyźnie interpretacji wewnątrzbiblijnej. Podkreślenie przez hagiografa zawartości poszczególnych wersetów wcześniejszych ksiąg świętych może okazać się niezwykle cenne w poszukiwaniach tego, 
co sam Bóg chciał zawrzeć - i co de facto uczynił - w materiale ksiąg uznanych przez Kościół za natchnione. Sami pisarze wskazują jednoznacznie, że Biblię należy traktować na pierwszym miejscu jako słowo Boga działającego w różnych momentach historii, w zmiennych warunkach i okolicznościach; działającego jednak zawsze w ten sam sposób: potwierdzając i umacniając to, co jest słuszne i godne pochwały, natomiast napominając i korygując to, co w ludzkim postępowaniu jest niewłaściwe.

\section{ks. Janusz NAWROT}

Słowa kluczowe: Biblia; Stary Testament; Księgi Kronik; Pierwsza Księga Machabejska; teologia biblijna

Keywords: Bible; Old Testament; The Books of Chronicles; The First Book of the Maccabees; biblical theology

\section{The Influence of the Theology of the Books of Chronicles on the First Book of Maccabees as Exemplified by 2 Chr 25,1-28 and 1 Macc 11 Summary}

The Old Testament includes many texts written by hagiographers that are later on taken up in a new or wider historical-theological context. In his work, the author of the First Book of Maccabees used earlier texts from the inspired books. He did not, however, quote them explicitly, but utilized chosen terminological borrowings. The material of the Books of Chronicles is part of the hagiographer's wider project of borrowing the theology of almost all the protocanonical books in order to strengthen his narration. He used descriptions of events, people and their behaviour which were a point of reference with regards to the evaluation of the action of particular characters during the time of the Maccabean Revolt. On the one hand, the theology of the previous biblical books lays the foundations for writing one's own original work. On the other hand, this work sheds meaningful light on the theological potential of the previous texts and thus opens them for the future. 


\section{Bibliografia}

B e a le G.K., C a r s on D.A. (red.), Commentary on the New Testament Use of the Old Testament, Grand Rapids 2007.

D y c k J. E., The Theocratic Ideology of the Chronicler, Leiden-Boston-Köln 1998.

G o o d R., The Septuagint's Translation of the Hebrew Verbal System in Chronicles, Leiden-Boston 2010.

Gu st a f s o n W., 2 Chronicles, w: S t e ve y W.S., W e s t D.E. (red.), What the Bible teaches, Ritchie Old Testament Commentaries, Kilmarnock 2013.

$\mathrm{H}$ a h n S. W., The Kingdom of God as Liturgical Empire: A Theological Commentary on 1-2 Chronicles, Grand Rapids 2012.

H o o k e r P. K., First and Second Chronicles, Louisville 2001.

$\mathrm{J}$ a c o b s B. M., S h e m- T o v Y., History: Issues in the Teaching and Learning of Jewish History, w: M i 11 e r H., G r a n t L.D., P o m s o n A., International Handbook of Jewish Education, cz. 1, Heidelberg-London-New York 2011, s. 441-460.

$\mathrm{J}$ a $\mathrm{p}$ h e t S., I and II Chronicles: A Commentary, Old Testament Literature, Louisville 1993.

$\mathrm{J}$ a $\mathrm{p}$ h e t S., The Ideology of the Book of Chronicles and Its Place in Biblical Thought, Beiträge zur Erforschung des Alten Testaments und des Antiken Judentums 9, Frankfurt-Bern-New York-Paris 1989.

J o h n s o n J. F., Analogia fidei as Hermeneutical Principle, Springfielder 36/1972-1973, s. 249-259.

K a i s e r W. C., Jr., Toward an Exegetical Theology: Biblical Exegesis for Preaching and Teaching, Grand Rapids 1981.

$\mathrm{K}$ e 11 y B. E., Retribution and Eschatology in Chronicles, The Journal for the Study of the Old Testament, Suppl. Series 211, Sheffield 1996.

$\mathrm{K} 1 \mathrm{e}$ i n R. W., 2 Chronicles, Hermeneia - A Critical and Historical Commentary of the Bible, Minneapolis 2012.

$\mathrm{L} \mathrm{i} \mathrm{g} \mathrm{h} \mathrm{s}$ t o $\mathrm{n}$ e J. N., Late Second Temple Judaism: A Recontruction and Re-description as a Religio-Cultural System, w: D a m m A. (red.), Religions and Education in Antiquity: Studies in Honour of Michel Desjardins, Leiden-Boston 2019, s. 76-106.

M e n $\mathrm{n}$ E., Inner-Biblical Exegesis in the Tanak, w: $\mathrm{H}$ a u s e r A.J., W a t s o $\mathrm{n}$ D.F. (red.), A History of Biblical Interpretation, t. 1: The Ancient Period, Grand Rapids-Cambridge 2003, s. 55-79.

N a w r o t J., Pierwsza Księa Machabejska - rozdziaty 1,1 - 6,16, Nowy Komentarz Biblijny ST XIV/1, Częstochowa 2016. 
N e w s o m e J. D. Jr., A Synoptic Harmony of Samuel, Kings, and Chronicles With Related Passages from Psalms, Isaiah, Jeremiah, and Ezra, Eugene 1986.

P o n i ż y B., Reinterpretacja Wyjścia Izraelitów z Egiptu w ujęciu Księgi Mądrości, Poznań 1991.

$\mathrm{R}$ a $\mathrm{p} \mathrm{p}$ a $\mathrm{p}$ o $\mathrm{r} \mathrm{U} .$, A Note on the Use of the Bible in 1 Maccabees, w: S t o $\mathrm{n}$ M.E., C h a z on E.G. (red.), Biblical Perspectives: Early Use and Interpretation of the Bible in Light of the Dead Sea Scrolls: Proceedings of the First International Symposium of the Orion Center 12-14 May 1996, Leiden-Boston-Köln 1998, s. 175-179.

$\mathrm{R}$ a $\mathrm{p}$ p a p o r t U., The First Book of Maccabees: Introduction, Hebrew Translation and Commentary, Jerusalem 2004.

Th o m p s o n J. A., 1-2 Chronicles. An Exegetical and Theological Exposition of Holy Scripture, New American Commentary 9, Nashville 1994.

Z v i B e n E., History, Literature and Theology in the Book of Chronicles, London-New York 2006. 